\title{
The Effect of Cash Flow Problems and Resource Intermingling on Small Business Recovery and Resilience After a Natural Disaster
}

\author{
Renee D. Wiatt ${ }^{1}\left[\right.$ I $\cdot$ Yoon G. Lee $^{2} \cdot$ Maria I. Marshall $^{3} \cdot$ Virginia S. Zuiker $^{4}$
}

Accepted: 7 September 2020 / Published online: 17 September 2020

(c) Springer Science+Business Media, LLC, part of Springer Nature 2020

\begin{abstract}
This study investigated the implications that cash flow problems and resource intermingling between the family and the business had on small business recovery and resilience after a natural disaster. This study contributed to the literature by studying the impact of cash flow problems and resource intermingling on small businesses in two separate periods: right after the natural disaster (period 1) and eight years after the disaster (period 2). Period 1 determined whether the business was in operation directly following Hurricane Katrina. Period 2 investigated success of the small business after Katrina (compared to pre-Katrina success). Results showed that cash flow problems and resource intermingling did not affect operational status directly following Katrina, but did play a role in business resilience in the long run.
\end{abstract}

Keywords Bootstrapping and resource · Cash flow problems · Intermingling $\cdot$ Natural disaster $\cdot$ Recovery and resilience Small businesses

Small businesses face resource exchanges between the family and the business, which can determine both short-term business success and long-term business sustainability. When business owners are under pressure from any disruption, the habitual ways of running the business may not

Renee D. Wiatt

reneewiatt@purdue.edu

Yoon G. Lee

yoon.lee@usu.edu

Maria I. Marshall

mimarsha@purdue.edu

Virginia S. Zuiker

vzuiker@umn.edu

1 Department of Agricultural Economics, Family Business Management Specialist, Purdue University, 403 West State Street, West Lafayette, IN 47907, USA

2 Department of Human Development and Family Studies, Utah State University, 2905 Old Main Hill, Logan, UT 84322-2905, USA

3 Department of Agricultural Economics, Purdue Institute for Family Business, Purdue University, 403 West State Street, West Lafayette, IN 47907, USA

4 Department of Family Social Science, University of Minnesota, 1985 Buford Avenue, St. Paul, MN 55108, USA suffice. Thus, business owners develop coping strategies by exchanging resources from either the family or business system. These coping strategies help business owners to overcome the disruption and maintain sustainability. One way that business owners do this is by intermingling the competing resources of both the family and business (Paul et al. 2003; Stafford et al. 1999). Financial intermingling occurs when family financial resources are used for business purposes, or business financial resources are used for family purposes.

Resource intermingling between the family and their business has been examined as two systems with varying degrees of dependence and overlap rather than as autonomous systems (Haynes and Avery 1996; Haynes et al. 2000; Muske et al. 2009; Yilmazer and Schrank 2006; Zuiker et al. 2002). Financial intermingling can include the use of business assets to support the household or the use of household assets for business needs. Small businesses have had less success in borrowing funds commercially and managing separate financial records between family and business systems, so financial bootstrapping may be considered. Financial bootstrapping entails alternative financial strategies in lieu of institutional borrowing (Winborg and Landström 2001). Consequently, resource intermingling can play a fundamental role in small business finances (Haynes et al. 1999, 2009; Haynes and Avery 1996). 
The current study focuses on the impacts of cash flow problems and financial intermingling between the family and the business on small business recovery and resilience after a natural disaster. Cash flow problems and financial intermingling/bootstrapping within a natural disaster framework is a gap in the literature. When a business is disrupted by a natural disaster, it may experience a multitude of challenges. Extenuating circumstances can increase the resource exchange between the business and the household due to the overlapping resources that the systems share (Stafford et al. 1999). The intermingling of financial resources between the household and business have been extensively examined in the family business literature (Carter and Van Auken 2006; Haynes and Avery 1996; Haynes et al. 1999; López-Gracia and Sánchez-Andújar 2007; McDonald and Marshall 2017; Muske et al. 2009; Yilmazer and Schrank 2006, 2010; Zuiker et al. 2002). The use of bootstrapping methods among small firms has been documented in the small business finance literature (Kneiding and Kritikos 2013; Neeley and Van Auken 2009; Van Auken 2004; Winborg and Landström 2001). Other studies have examined how the family and business systems influence business resilience (Haynes et al. 2011; Torres et al. 2018). However, relatively little attention has been given to the effect intermingling between business and family finances has on small businesses after non-normative disruptions. Furthermore, little is known about how cash flow problems in small firms influence business recovery and resilience after a natural disaster.

\section{Review of Literature}

Investigating the interconnectivity of family and business finances is a phenomenon that researchers have studied for over 20 years. Yilmazer and Schrank (2006) noted that family businesses had different intermingling of household and business financial resources than non-family businesses. Intertwining the family and business finances influenced family business successes and sustainability (Lee and Stafford 2013; Olson et al. 2003). In investigating the systems' intermingling, any assessment of the well-being of one system is incomplete without an assessment of the other (Haynes et al. 1999; Yilmazer and Schrank 2010; Zuiker et al. 2002). The overlapping family and business system demands can cause a ripple effect; increasing demands in one system can lead to change in the other system (Lee et al. 2015; Niehm et al. 2009). When small business owners intertwine their personal and business debts, this intermingling can add more financial burden to both systems.

There are a variety of ways of intermingling business and family finances (e.g., taking a direct loan or grant from the family members, loaning money to the family, and using personal assets as collateral for business loans) (Haynes and
Avery 1996). The findings suggest that family business owners were more likely to borrow from commercial banks or from their own family members compared to households who were not business owners. Financial distress costs and internal resources were important determinants of the financial behavior of small family businesses than non-family businesses (López et al. 2007).

Haynes et al. (1999) found that financial intermingling was more likely when a family-owned business was a sole proprietorship, owed money to financial institutions, had an older and more experienced owner, and had a childless owner. Sole proprietors were more likely to use family resources in the business compared to more formal businesses structures. Family-owned businesses located in rural and small towns were more likely to intermingle resources than those in urban areas. Women business owners were more likely to intermingle resources than male business owners.

Zuiker et al. (2002) examined a nationally representative sample of family-owned businesses and found that the intermingling variables contributed to cash flow problems in the business system. When resource intermingling characteristics were compared between family businesses with and without cash flow problems, Zuiker et al. (2002) found that owners with business cash flow problems tended to be younger, worked more hours, and had higher levels of total debts. Business owners with cash flow problems in both systems were more likely to report intermingling of finances between the two systems than their counterparts (Zuiker et al. 2002). McDonald and Marshall (2018) found that family business owners responded to cash-flow problems by decreasing their percentage contribution to household income, but owners did not respond in the same way to household cash-flow problems. It is evident that cash flow problems lead to a higher probability of resource intermingling between the family and business systems.

Copreneurial couples are defined as couples that share a personal relationship and the operation/management of a business. Muske et al. (2009) found that copreneurial business owners intermingled financial resources more often than non-copreneurial business owners. When copreneurial owners used their home as collateral, business profit increased. Muske et al. (2009) reported that copreneurial couples more often used business property as collateral to meet family needs and also used family assets and household income to meet business needs.

\section{Bootstrapping and System Intermingling}

Financial bootstrapping is a phenomenon that is occurring more and more often in small and family businesses. Winborg and Landström (2001) referred to financial bootstrapping as using alternative methods to meet business resource 
needs instead of borrowing money from an institution. They identified six different bootstrapping methods that small business owners often use. In another study, Van Auken (2004) examined the use of bootstrapping financing methods among small firms, while focusing on the advantage of bootstrap financing as an important source of financial resources for small firms.

Previous studies (Haynes et al. 1999, 2000, 2007; Muske et al. 2009) consistently documented that the financial structure of the family business was different from their nonfamily counterparts. One study found that financial intermingling was not significantly different between family businesses and non-family businesses, however, business characteristics and household net worth influenced more financial intermingling (Yilmazer and Schrank 2006). Bootstrapping methods included seeking and implementing funding not generated in the business to fund said business, such as utilizing family or household funding (Neeley and Van Auken 2009). Yilmazer and Schrank (2010) stated that since owner resource bootstrapping and intermingling can place some risks on the household and the business, the use of owner resources should be understood in a holistic perspective.

Bootstrapping methods can be crucial to small business success. Neeley and Van Auken (2009) examined the relationship between owner characteristics and the use of bootstrapping financial methods among small firms. Their findings suggested that owners with higher education, who were younger, and male were more likely to acquire resources through self-funding bootstrap financing (Neeley and Van Auken 2009). Based on prior research, the use of bootstrap financing could be useful in times of disruption.

Both family and owner responses to disruptions (normative or non-normative) had a significant impact on gross revenue and owner's perceived success (how successful the business owner gauges his or her own business) (Lee et al. 2015; Olson et al. 2003). Olson et al. (2003) indicated that business success was influenced more by family factors than business factors. Business owners who had cash flow problems in both the business and the household had lower perceived business success (Zuiker et al. 2002). Muske et al. (2009) explained that when copreneurial owners used business cash for the family, perceived business success decreased. Business continuity was influenced by family decisions, life events and owner resiliency (Winter et al. 2004).

The most successful family businesses were strong businesses, supported by strong families (Haynes et al. 2007). Olson et al. (2003) found that family businesses with cash flow problems had lower gross business revenue than businesses without cash flow problems. In addition, cash flow problems in the business resulted in the business manager having a lower perceived business success. Moreover, cash flow problems negatively influenced family functioning. When the business used family income to meet business cash flow problems, gross business revenue was negatively impacted. Business-owning families with a higher functional integrity were more likely to use their income to solve business cash flow problems than families with a lower functional integrity score. According to this study, intermingling between families and their businesses negatively influenced business revenue and owner's perceived success.

Danes et al. (2009) examined how family human capital, financial capital, and social capital were associated with owner's perceived success. They revealed that in the short term, family human capital and financial capital contributed more to owners' perceived business success than family social capital, whereas family social capital contributed more to the success perception in the long term (Danes et al. 2009). Family financial capital was important in the owner's view of business success such that when a natural or manmade disaster occurred, the business owner could combine business and family financial capital to recover from a disaster. It can be inferred that family firms could utilize all three types of capital (e.g., human, financial, and social) for sustainability of family-owned firms. However, during financially difficult times when financial capital may be lacking, human and social capital become crucial for small business survival and recovery.

There have been few studies investigating how natural disasters affect small family firms (Marshall and Schrank 2014; Marshall et al. 2015; Sydnor et al. 2016). Marshall et al. (2015) proposed a research model for small business recovery that categorized small businesses within the disaster recovery process. They stressed that small business disaster recovery should encompass the individual, family, and community context, as these factors are important in recovery from a natural disaster. Adekola and Clelland (2019) also found that rural, small businesses had a major influence on community resilience after natural disasters. Small business owners were often volunteers who contributed individually to community recovery. Torres et al. (2018) measured the effect that social capital had on small business resilience. They compared pre- and post-Katrina success and income to form economic and attitudinal resilience measurements, which we adopted in this study to measure resilience.

In another study, Marshall et al. (2015) examined what factors influenced small business demise after a natural disaster. They focused on pre-existing characteristics of businesses and owners. Their findings suggested that owner characteristics such as minority groups, female-owned businesses, and veterans were more likely to meet business demise after a natural disaster. The authors noted that when businesses had prior disaster and recovery experience, the business owners were more prepared for disasters and that reduced their chances of business demise. Runyan (2006) 
interviewed small business owners who experienced Katrina, and an overwhelmingly crucial barrier to recovery for the business was cash flow problems.

Sydnor et al. (2016) focused on the severity of damages that natural disasters caused on small businesses and how these factors affected the operating status of the firms. Their findings suggested that damage from natural disasters could have a short-term effect on business operations. However, damage did not significantly affect small business operations in the long run. Several studies have attempted to predict the factors of small firms' demise, recovery, or survival after a natural disaster (Marshall and Schrank 2014; Marshall et al. 2015; Sydnor et al. 2016). While focusing on overlapping family and business demands in the context of natural disasters, these studies have addressed the challenges of overcoming the shocks originating from a natural disaster. Although there have been several studies on how natural disasters affect small business survival and success, less is known about how small firm owners respond to the disruption from a natural disaster-the intermingling of financial resources between family and business-affects business recovery.

\section{Theoretical Framework: Conceptual Model}

We adapted Marshall and Schrank's (2014) Small Business Disaster Recovery Framework (SBDRF) to guide our vocabulary and analysis. The SBDRF shows that as businesses that have experienced a disaster move through time, they go through three distinct stages. The three stages were measured by three different periods. For each given period, different statuses can be assigned to a business. The statuses included in this analysis were operating, not operating, demised, survived, recovered, and resilient. Businesses that were permanently closed were categorized as "demised". It is important to note that demised businesses are not synonymous to those not operating. Survived businesses were those that were still operating, but were not as well off as they were before the disaster. Recovered businesses were those that were operating and have returned to some pre-disaster level. Businesses categorized as "resilient" were those that were operating at a higher level than they were pre-disaster.

For period one (immediately following the disaster event), the businesses could be either operating or not operating. For period one in this analysis, we measured whether or not the business closed due to Hurricane Katrina. For period two, those businesses that remained operational could be demised, survived, recovered, or resilient. Conversely, those businesses that were not operating in period one could be demised, survived or recovered. There is a third period in the SBDRF, but for this analysis only periods one and two were analyzed.
Along with the SBDRF, the Sustainable Family Business Model (SFBM) was used to characterize the overlap that occurs between the family and business systems (Stafford et al. 1999). The SFBM allows for the overlap of family and business, which have a very large influence on each other in small and family businesses (Haynes et al. 2011). The SFBM demonstrates that the family and the business both have resources and constraints. Given a disruption in either system, the family and the business can pull resources from both systems to eventually attain a state of sustainability. We applied the SFBM in a disaster framework in order to analyze the effect that cash flow problems (both pre- and post-disaster) had on the small business that experienced a disaster (Hurricane Katrina). We also applied the SFBM in a disaster framework to analyze the effects of resource intermingling between the family and the business.

\section{Hypotheses}

Based on past literature and the gap in the literature surrounding cash flow problems and businesses experiencing disaster, this study presents the following hypotheses: H1a-Business cash flow problems pre-Katrina are negatively associated with business recovery after Katrina. $\mathrm{H} 1 \mathrm{~b}$-Financial intermingling of family and business are negatively associated with business recovery after Katrina. $\mathrm{H} 2 \mathrm{a}-$ Business cash flow problems post-Katrina are negatively associated with business resilience after Katrina. $\mathrm{H} 2 \mathrm{~b}$ - Financial intermingling of family and business are negatively associated with business resilience after Katrina.

\section{Methods}

\section{Data}

The data for this study were comprised of small businesses in a 10-county region in southern Mississippi who were operating in 2004. The businesses in the sample had experienced Hurricane Katrina in August of 2005. The ten counties were in the right front quadrant of Hurricane Katrina. Some businesses that were operating during Hurricane Katrina closed because of Katrina, some were closed by the owner (e.g., sold, retired, or gifted) after Katrina, and some were open and operating with the same owner at the time of the survey. The data were gathered in three waves: wave one in 2013 by telephone interviews and waves two (2014) and three (2015) through mail survey. Only the data from wave one was used in this analysis of pre and post Katrina intermingling.

Wave one data was originally drawn from a Dun and Bradstreet database for small businesses operating in the chosen 10-county region of Mississippi. Small business 
in this study was defined as a business with 200 or fewer employees. A sample of 5,500 small businesses that were operating in the ten target counties prior to Hurricane Katrina and headquartered in Mississippi were randomly selected. Because of various selection problems from the list provider, 623 businesses were screened out, leaving 4877 to be fielded. Of the 4877 cases fielded, 2610 businesses were eligible with contact information. Of the 2610 business owners reached, the cooperation rate was $19.12 \%$ providing a sample size of 499 businesses.

\section{Dependent Variable}

The dependent variable for the probit regression was Survived_Katrina and the dependent variable for the ordered probit regression was Success_Katrina. Survived_Katrina was a binary variable that specified whether a business was closed by Katrina, to indicate operational status. This binary variable took the value of one if the business was open and currently operating with the same owner, reopened after Katrina, but was not currently operating, or was closed by the owner, sold, retire, or gifted at some point after Katrina. The variable took a value of zero if the business was closed by Hurricane Katrina.

Success_Katrina was constructed to measure resilience after Katrina and represents three distinct states of recovery: Survived (less successful than pre-Katrina), recovered (same success as pre-Katrina), and resilient (more successful than pre-Katrina). Success levels were based on the owner's perceived success before and after Katrina of his or her own business. Respondents were asked using a 5-point Likert scale how successful their businesses were before Katrina and after Katrina. Answers to the two questions were compared to construct the three outcomes of survived (perceived success after Katrina was lower than before Katrina), recovered (perceived success after Katrina was the same as before Katrina), and resilient (perceived success after Katrina was the higher than before Katrina). Survived_Katrina was used as a proxy for business recovery, just as Success_Katrina was a proxy for small business resilience.

\section{Independent Variables}

The independent variables included two variables of interest (i.e., business cash flow problems and resource intermingling between the family and the business systems). The resource intermingling variable (use_fam_fund_biz) was a scale valued between zero and three. The three items included in the scale were: (1) using household savings for business needs, (2) using a family asset such your home or car for business purposes, and (3) borrowing from family members. A point was added to the scale for each of the practices that businesses utilized, whereas a score of zero was assigned when the business did not do any of the three intermingling practices.

Control variables included in the two models represent characteristics of the owner, the business, and the disaster, Hurricane Katrina. Owner characteristics included gender, marital status, and the owner's years of experience in the industry. Business variables included home-based business indicators, legal structure of the business, service industry, business age, and number of employees (i.e., business size). Disaster variables included major damage sustained by the business from Hurricane Katrina and whether or not the business was in a coastal county at the time of Katrina (coastal businesses were more likely to sustain damage). Table 1 shows the definitions and measurements of all dependent and independent variables.

\section{Empirical Models}

This study explicitly investigates the way cash flow problems (or lack thereof) and financial and resource intermingling between the family and the business played a part in small business recovery and resilience after a natural disaster. To achieve research objectives, two empirical models were employed for this study: (1) a probit regression, and (2) an ordered probit regression. Both the probit regression and ordered probit regression were discrete choice models. Specifically, the dependent variable in the probit model was binary, whereas the dependent variable in the ordered probit regression was a discrete choice variable with integer values ranging from one to three. Marginal effects that were calculated post-estimation on the probit regression forced a normal distribution on the sample (Greene 2002).

The probit model in the analysis sought to measure the probability of small businesses still being operational after experiencing Hurricane Katrina. A general probit model took the following form (Greene 2002; Wooldridge 2013):

$\mathrm{P}(\mathrm{y} *=1 \mid \mathbf{x})=\mathrm{P}(\mathrm{y} *=1 \mid \mathrm{x} 1, \mathrm{x} 2, \ldots, \mathrm{xk}) \operatorname{or} \operatorname{Prob}(\mathrm{Y}=1 \mid \mathbf{x})=\phi x^{\prime} \beta$

where $\phi$ is the function, $\mathrm{y}^{*}$ is the unobserved dependent variable, $\mathbf{x}$ is the matrix of characteristic variables, $Y$ is the set of observed dependent variables, and $\beta$ is the set of coefficients for the independent variables.

The ordered probit model in the analysis was employed to measure the recovery and resilience of small businesses after experiencing Hurricane Katrina. A general multivariate (ordered) probit model took the following form (Greene 2002):

$\mathrm{y} *=\mathbf{x}^{\prime} \beta+\varepsilon$

or 
Table 1 Variable names and definitions

\begin{tabular}{|c|c|}
\hline \multicolumn{2}{|l|}{ Dependent variables } \\
\hline surived_Katrina & $\begin{array}{l}=1 \text { if business was open and currently operating with the same owner; reopened after Katrina but not currently } \\
\text { operating; or closed by owner, sold, retired, or gifted; }=00 \text { if business was closed by Katrina }\end{array}$ \\
\hline \multirow[t]{3}{*}{ success_Katrina } & $\begin{array}{l}=1 \text { if the owner states that the pre-Katrina level of business success is higher than post-Katrina level of success (less } \\
\text { successful after Katrina), survived }\end{array}$ \\
\hline & $\begin{array}{l}=2 \text { if the owner states the pre-Katrina level of business success is same as the post-Katrina level of success (same } \\
\text { success before/after Katrina), recovered }\end{array}$ \\
\hline & $\begin{array}{l}=3 \text { if the owner states that the pre-Katrina level of business success is lower than post-Katrina level of success } \\
\text { (more successful after Katrina), resilient }\end{array}$ \\
\hline \multicolumn{2}{|l|}{ Independent Variables } \\
\hline \multirow[t]{2}{*}{ biz_cash_flow_pre_K } & $\begin{array}{l}=1 \text { if business had cash flow problems frequently (every quarter, week, or month) prior to August of } 2005 \text { (pre- } \\
\text { Katrina) }\end{array}$ \\
\hline & $\begin{array}{l}=0 \text { if business experienced cash flow problems infrequently (once or twice a year or never) prior to August of } 2005 \\
\text { (pre-Katrina) }\end{array}$ \\
\hline \multirow[t]{2}{*}{ biz_cash_flow_post_K } & $=1$ if business had cash flow problems frequently (every quarter, week, or month) after Katrina \\
\hline & $=0$ if business experienced cash flow problems infrequently (once or twice a year or never) after Katrina \\
\hline use_fam_fund_biz & $\begin{array}{l}\text { scale (range } 0-3 \text { ), one point for each of the following that was done before Katrina: (1) use household savings for } \\
\text { business needs, (2) use a family asset such your home or car for business purposes, and (3) borrow from family } \\
\text { members; }=0 \text { if otherwise }\end{array}$ \\
\hline \multirow[t]{2}{*}{ major_damage_Katrina } & $=1$ if Katrina caused catastrophic damage to the business facility or if major repairs were needed before reopening \\
\hline & $=0$ Katrina caused very little to no damage or some repair work was needed \\
\hline \multirow[t]{2}{*}{ pre_corp_partnership } & $=1$ if the business is in a legal partnership or some form of corporation \\
\hline & $=0$ if business is a sole proprietorship \\
\hline \multirow[t]{2}{*}{ services } & $=1$ if the business is in a service industry \\
\hline & $=0$ if business is not in a service industry \\
\hline \multirow[t]{2}{*}{ married } & $=1$ if the owner is married \\
\hline & $=0$ if the owner is single, never married, divorced, separated, or widowed \\
\hline \multirow[t]{2}{*}{ female } & $=1$ if the owner is female \\
\hline & $=0$ if the owner is male \\
\hline owner_experience & years of experience the owner has in his or her current industry (continuous) \\
\hline business_age & age of business in years (continuous) \\
\hline number_of_employees & number of employees working for the business, pre-Katrina (continuous) \\
\hline home_based_biz & $\begin{array}{l}=1 \text { if the business was operating from the owner's home (on residential property) at the time of Katrina; }=0 \text { if not } \\
\text { operate from the owner's home }\end{array}$ \\
\hline $\begin{array}{l}\text { coastal (used as a cluster } \\
\text { control for the regres- } \\
\text { sions) }\end{array}$ & $=1$ if the business is in a coastal county $=0$ if not in a coastal county \\
\hline
\end{tabular}

$\operatorname{Prob}(\mathrm{y}=1 \mid \mathbf{x})=\phi\left(\mu_{1}-x^{\prime} \beta\right)-\phi\left(-x^{\prime} \beta\right)$

$\operatorname{Prob}(\mathrm{y}=2 \mid x)=\phi\left(\mu_{2}-x^{\prime} \beta\right)-\phi\left(\mu_{1}-x^{\prime} \beta\right)$

$\operatorname{Prob}(\mathrm{y}=3 \mid x)=1-\phi\left(\mu_{3}-x^{\prime} \beta\right)$

In order for each probability to be greater than zero,

$0<\mu_{1}<\mu_{2}<\mu_{3}$

where $\phi$ is the function, $\mathrm{y}^{*}$ is the unobserved dependent variable, $\mathbf{x}$ is the matrix of characteristic variables, $\mathrm{Y}$ is the set of observed dependent variables, $\beta$ is the set of coefficients for the independent variables and $\varepsilon$ is the standard error.

\section{Findings}

\section{Descriptive Results}

Table 2 contains the means and standard deviations of each variable, grouped by recovery and resilience. It shows that $16 \%$ of the businesses that survived Katrina had cashflow problems before Katrina. In contrast, after Katrina $82 \%$ of survived businesses had cash flow problems compared to $68 \%$ of resilient businesses; $57 \%$ of businesses without a change in success had cash flow problems after Katrina. It 
Table 2 Means and Standard Deviations of Variables by Survival and Success

\begin{tabular}{|c|c|c|c|c|c|}
\hline & \multicolumn{2}{|l|}{$\begin{array}{l}\text { Recovery } \\
(\mathrm{N}=449)\end{array}$} & \multicolumn{3}{|l|}{$\begin{array}{l}\text { Resilience } \\
(\mathrm{N}=357)\end{array}$} \\
\hline & $\begin{array}{l}\text { Survived Katrina } \\
(\mathrm{n}=411)\end{array}$ & $\begin{array}{l}\text { Did not survive } \\
\text { Katrina } \\
(\mathrm{n}=38)\end{array}$ & $\begin{array}{l}\text { Less success after } \\
\text { Katrina (Survived) } \\
(\mathrm{n}=163)\end{array}$ & $\begin{array}{l}\text { Same success after } \\
\text { Katrina (Recovered) } \\
(n=156)\end{array}$ & $\begin{array}{l}\text { More success after } \\
\text { Katrina (Resilient) } \\
(\mathrm{n}=38)\end{array}$ \\
\hline \multirow[t]{2}{*}{ biz_cash_flow_pre_K ${ }^{\dagger}$} & 0.16 & 0.13 & - & - & - \\
\hline & 0.02 & 0.06 & - & - & - \\
\hline \multirow[t]{2}{*}{ biz_cash_flow_post_K $\mathrm{K}^{\dagger}$} & - & - & $0.82^{\ddagger}$ & $0.57^{\ddagger}$ & $0.68^{\ddagger}$ \\
\hline & - & - & 0.03 & 0.04 & 0.08 \\
\hline \multirow[t]{2}{*}{ pre_use_fam_fund_biz } & 0.88 & 0.89 & - & - & - \\
\hline & 0.05 & 0.15 & - & - & - \\
\hline \multirow[t]{2}{*}{ post_use_fam_fund_biz } & - & - & $1.40^{\ddagger}$ & $0.71^{\ddagger}$ & $0.97^{\ddagger}$ \\
\hline & - & - & 0.07 & 0.07 & 0.17 \\
\hline \multirow[t]{2}{*}{ major_damage_Katrina ${ }^{\dagger}$} & $0.47^{\ddagger}$ & $0.89^{\ddagger}$ & $0.55^{\ddagger}$ & $0.35^{\ddagger}$ & $0.55^{\ddagger}$ \\
\hline & 0.02 & 0.05 & 0.04 & 0.04 & 0.08 \\
\hline \multirow[t]{2}{*}{ pre_corp_partnership ${ }^{\dagger}$} & 0.55 & 0.42 & $0.46^{\ddagger}$ & $0.64^{\ddagger}$ & $0.66^{\ddagger}$ \\
\hline & 0.02 & 0.08 & 0.04 & 0.04 & 0.08 \\
\hline \multirow[t]{2}{*}{ services $^{\dagger}$} & $0.36^{\ddagger}$ & $0.21^{\ddagger}$ & 0.42 & 0.35 & 0.29 \\
\hline & 0.02 & 0.07 & 0.04 & 0.04 & 0.07 \\
\hline \multirow[t]{2}{*}{ married $^{\dagger}$} & 0.83 & 0.89 & 0.80 & 0.87 & 0.82 \\
\hline & 0.02 & 0.05 & 0.03 & 0.03 & 0.06 \\
\hline \multirow[t]{2}{*}{ female $^{\dagger}$} & 0.31 & 0.39 & 0.32 & 0.27 & 0.24 \\
\hline & 0.02 & 0.08 & 0.04 & 0.04 & 0.07 \\
\hline \multirow[t]{2}{*}{ owner_experience } & $29.64^{\ddagger}$ & $23.24^{\ddagger}$ & 31.26 & 29.90 & 26.97 \\
\hline & 0.60 & 2.25 & 0.91 & 0.90 & 2.08 \\
\hline \multirow[t]{2}{*}{ business_age } & 32.52 & 30.66 & $35.22^{\ddagger}$ & $33.08^{\ddagger}$ & $27.24^{\ddagger}$ \\
\hline & 0.83 & 2.64 & 1.50 & 1.34 & 1.56 \\
\hline \multirow[t]{2}{*}{ number_of_employees } & 6.34 & 2.79 & $4.28^{\ddagger}$ & $9.13^{\ddagger}$ & $7.24^{\ddagger}$ \\
\hline & 0.67 & 0.40 & 0.42 & 1.58 & 2.20 \\
\hline \multirow[t]{2}{*}{ home_based_biz ${ }^{\dagger}$} & 0.31 & 0.29 & 0.35 & 0.28 & 0.26 \\
\hline & 0.02 & 0.07 & 0.04 & 0.04 & 0.07 \\
\hline
\end{tabular}

${ }^{\dagger}$ The mean is the percentage of respondents with that attribute per category

${ }^{\ddagger}$ Means across groups are statistically different at the $10 \%$ level

can be seen that $88 \%$ of businesses that survived Katrina used family funds in their business, while $89 \%$ of businesses that did not survive Katrina used family funds in their business. Hence, most small businesses used family funds in their business, regardless of survival. Table 2 also demonstrates that survived businesses utilized more family resources for the business (score of 1.40 on the scale) compared to recovered businesses (score of 0.71 on the scale) and resilient businesses (score of 0.97 on the scale). Exploring differences in recovery means, only $47 \%$ of survived businesses experienced major damage from the storm and roughly $89 \%$ of businesses that did not survive experienced major damage. When examining the level of resilience and reporting storm damage, survived and resilient businesses reported having major storm damage (55\% each) versus recovered businesses (35\%). Legal structure of the business varied based on resilience level of the business; $46 \%$ of less successful businesses had a legal business structure (i.e. corporation or partnership), $64 \%$ of the 'same success' businesses had a legal business structure, and $66 \%$ of more successful businesses had a legal business structure. Twentyone percent of businesses that did not survive were in the service industry, compared to $36 \%$ of businesses that did survive the storm. Owners with more years of experience in his or her current industry were more likely to have survived businesses. Survived businesses were roughly 35 years old, recovered businesses were 33 years old, and resilient businesses were 27 years old. Mean number of employees was significant across groups (survived, recovered, and resilient), as survived businesses had an average of four employees, recovered businesses had nine, and resilient businesses had seven employees. Based on these findings, businesses with 
more than four employees were more likely to experience same or more success post Katrina, showing the important role that business size plays in business success.

\section{Regression Results}

We analyzed the effects of cash flow and financial intermingling on recovery and resilience of small businesses after Hurricane Katrina. Small business recovery was estimated using a probit regression. Small business resilience was estimated utilizing an ordered probit regression. Table 3 presents the results from both regression analyses. The probit regression (measuring recovery) revealed a negative relationship between major damage from Katrina and the likelihood of business recovering. Formal business structure such as corporation or partnership increased the likelihood of business recovery. Service industry businesses,

Table 3 Probit and ordered probit regression results

\begin{tabular}{|c|c|c|c|c|}
\hline & \multicolumn{2}{|c|}{ Probit Results } & \multicolumn{2}{|c|}{$\begin{array}{l}\text { Ordered Probit } \\
\text { Results }\end{array}$} \\
\hline & \multicolumn{2}{|c|}{$\begin{array}{l}\text { Survived_Katrina } \\
\text { Recovery }\end{array}$} & \multicolumn{2}{|c|}{$\begin{array}{l}\text { Success_Katrina } \\
\text { Resilience }\end{array}$} \\
\hline & Coefficient & $\begin{array}{l}\text { Robust } \\
\text { standard } \\
\text { error }\end{array}$ & Coefficient & $\begin{array}{l}\text { Robust } \\
\text { standard } \\
\text { error }\end{array}$ \\
\hline $\begin{array}{l}\text { biz_cash_flow_ } \\
\text { pre_K }\end{array}$ & -0.02 & 0.27 & - & - \\
\hline $\begin{array}{l}\text { biz_cash_flow_ } \\
\text { post_K }\end{array}$ & - & - & $-0.15^{* * *}$ & 0.03 \\
\hline use_fam_fund_biz & 0.07 & 0.22 & $-0.28 * * *$ & 0.06 \\
\hline $\begin{array}{l}\text { major_damage_ } \\
\text { Katrina }\end{array}$ & $-1.24 * *$ & 0.48 & $-0.09^{\dagger}$ & 0.05 \\
\hline $\begin{array}{l}\text { pre_corp_partner- } \\
\text { ship }\end{array}$ & $0.25^{* * *}$ & 0.05 & $0.26^{*}$ & 0.13 \\
\hline services & $0.46 * * *$ & 0.09 & $-0.27 * * *$ & 0.06 \\
\hline married & $-0.37 * *$ & 0.13 & -0.04 & 0.13 \\
\hline female & $-0.13 * * *$ & 0.02 & $-0.16^{* * *}$ & 0.01 \\
\hline owner_experience & 0.02 & 0.02 & $-0.01 * * *$ & 0.00 \\
\hline business_age & 0.00 & 0.00 & $-0.01 * * *$ & 0.00 \\
\hline $\begin{array}{l}\text { number_of_- } \\
\text { employees }\end{array}$ & $0.07 * * *$ & 0.00 & $0.01^{\dagger}$ & 0.00 \\
\hline home_based_biz & $0.29 * * *$ & 0.07 & -0.03 & 0.08 \\
\hline constant & $1.41 * * *$ & 0.40 & - & - \\
\hline cut1 & - & - & -1.12 & 0.31 \\
\hline cut2 & - & - & 0.36 & 0.08 \\
\hline $\begin{array}{l}\text { Number Observa- } \\
\text { tions }\end{array}$ & \multicolumn{2}{|l|}{449} & \multicolumn{2}{|l|}{357} \\
\hline $\begin{array}{l}\text { Log pseudolikeli- } \\
\text { hood }\end{array}$ & \multicolumn{2}{|l|}{-102.29} & \multicolumn{2}{|l|}{-315.56} \\
\hline \multirow[t]{2}{*}{ Pseudo R2 } & \multicolumn{2}{|l|}{0.2143} & \multicolumn{2}{|l|}{0.0775} \\
\hline & \multicolumn{4}{|c|}{ Standard errors adjusted for 2 clusters in coast } \\
\hline
\end{tabular}

businesses with more employees, and home-based businesses had higher likelihoods of recovery. Businesses with married and/or female owners were less likely to recover from Hurricane Katrina.

The ordered probit regression had more variables that were statistically significant to resilience than the probit model to recovery. Business cash flow problems (after Katrina), using the family to fund the business, and major damage from Katrina all had negative associations with resilience. Other factors that had a negative association with resilience were service industry classification, having female business owners, owner experience, and business age. Formal business structure (corporation/partnership) as well as number of employees had a positive association with the likelihood that a business was resilient.

\section{Recovery: Marginal Effects After the Probit Regression}

Table 4 shows marginal effects after the probit regression from the coefficient associated with cashflow and financial intermingling variables. Both the coefficients associated with cashflow problems and financial intermingling were not statistically significant. Thus, both the H1a (Business cash flow problems pre-Katrina are negatively related with business recovery after Katrina) and H1b (Financial intermingling of family and business are negatively correlated with business recovery after Katrina) were not supported. For example, the results of the probit regression shows that cash flow problems before the disaster occurred and financial intermingling between the business and the family had no influence on small business survival in the short-run.

Major damage resulted in a reduced likelihood of small business survival in the short-run. Small businesses that sustained major damage from Hurricane Katrina were 10\% less likely to survive compared to businesses that did not

Table 4 Marginal effects after probit (recovery)

\begin{tabular}{lcc}
\hline Variables & $\mathrm{dy} / \mathrm{dx}$ & Std. Err \\
\hline biz_cash_flow_pre_K & 0.00 & 0.02 \\
use_fam_fund_biz & 0.01 & 0.01 \\
major_damage_Katrina & $-0.10^{* * *}$ & 0.03 \\
pre_corp_partnership & $0.02^{* *}$ & 0.01 \\
services & $0.03^{* *}$ & 0.01 \\
married & $-0.02^{*}$ & 0.01 \\
female & $-0.01^{* * *}$ & 0.00 \\
owner_experience & $0.00^{*}$ & 0.00 \\
business_age & 0.00 & 0.00 \\
number_of_employees & $0.00^{* * *}$ & 0.00 \\
home_based_biz & $0.02^{*}$ & 0.01 \\
\hline
\end{tabular}

${ }^{\dagger} p<0.10, * p<0.05, * * p<0.01, * * * p<0.001$ 
sustain major damage from the storm. Businesses in the service industry and home-based businesses were 3\% and 2\% (respectively) more likely to survive Katrina than non-service and non-home-based businesses. Businesses in a legal partnership or corporation were $2 \%$ more likely to survive Katrina than those without a formal legal structure. Married business owners and female business owners were less likely to have their business survive Katrina than their counterparts ( $2 \%$ and $1 \%$, respectively).

\section{Resilience: Marginal Effects After the Ordered Probit Regressions}

Table 5 shows marginal effects after the ordered probit regressions. Unlike the probit regression on business survival, the coefficients associated with cash flow problems and financial intermingling were statistically significant in the ordered probit model focused on resilience. Measuring resilience can be troublesome, but we modeled it in three phases adapting Marshall and Schrank's (2014) Small Business Disaster Recovery Framework (SBDRF). Success_Katrina took a value of one if business success was lower after Katrina than before (survived), it took a value of two if perceived success was the same before and after Katrina (recovered), and it took a value of three if business success was higher after Katrina (resilient).The findings suggest that cash flow problems and financial intermingling did have a negative effect on small business resilience after Hurricane Katrina. Thus, H2a (Business cash flow problems post-Katrina are negatively related with business resilience after Katrina.) and $\mathbf{H 2 b}$ (Financial intermingling of family and business are negatively related with business resilience after Katrina.) were supported.
Exploring the marginal effects after the ordered probit model gave a unique insight to the states of resilience after a natural disaster: survived, recovered, and resilient. Businesses were $6 \%$ more likely to be in the survived state, $3 \%$ less likely to be recovered, and $2 \%$ less likely to be resilient if that business had cash flow problems after Katrina. Businesses were $11 \%$ more likely to be survived, $7 \%$ less likely to be recovered, and $4 \%$ less likely resilient if the family intermingles finances to fund the business. Businesses in the service industry were $11 \%$ more likely to be survived, $7 \%$ less likely to be recovered, and $4 \%$ less likely to be resilient. Having a female owner made businesses $6 \%$ more likely to be survived, $4 \%$ less likely to be recovered, and $2 \%$ less likely to be resilient. Businesses with a formal legal structure (i.e. corporation or partnership) were $10 \%$ less likely to be survived and 6\% more likely to be recovered. Previously discussed results suggest that in terms of recovery, the following characteristics give businesses a disadvantage: financial intermingling, business cash flow problems after Katrina, major storm damage, service industry, female owner, homebased business, and no formal legal structure.

\section{Discussion, Conclusion, and Implications}

Any natural disaster can have huge impacts on business functioning, and Hurricane Katrina was no exception. Businesses that experienced Katrina were likely to experience dislocation of the business owner as well as dislocation of the customer base, making recovery even more problematic (Corey and Deitch 2011). Survival, recovery, and resilience are difficult to measure. However, integrating Marshall and Schrank's (2014) Small Business Disaster Recovery Framework (SBDRF) into the data allowed for such measurements.
Table 5 Marginal effects after ordered probit (resilience)

\begin{tabular}{|c|c|c|c|c|c|c|}
\hline & \multirow{2}{*}{\multicolumn{2}{|c|}{$\begin{array}{l}\text { Less success after } \\
\text { Katrina (Survived) } \\
\text { Success_Katrina }=1\end{array}$}} & \multirow{2}{*}{\multicolumn{2}{|c|}{$\begin{array}{l}\text { Same success after Kat- } \\
\text { rina (Recovered) }\end{array}$}} & \multirow{2}{*}{\multicolumn{2}{|c|}{$\begin{array}{l}\begin{array}{l}\text { More success after Katrina } \\
\text { (Resilient) }\end{array} \\
\text { Success_Katrina }=3\end{array}$}} \\
\hline & & & & & & \\
\hline & $\mathrm{dy} / \mathrm{dx}$ & Standard Err & $\mathrm{dy} / \mathrm{dx}$ & Standard Err & $\mathrm{dy} / \mathrm{dx}$ & Standard Err \\
\hline biz_cash_flow_post_K & \multicolumn{2}{|c|}{$0.06 * * * 0.01$} & $-0.03 * * *$ & 0.00 & $-0.02 * * *$ & 0.01 \\
\hline use_fam_fund_biz & \multicolumn{2}{|c|}{$0.11 * * * 0.02$} & $-0.07 * * *$ & 0.02 & $-0.04 * * *$ & 0.00 \\
\hline major_damage_Katrina & $0.04^{\dagger}$ & 0.02 & $-0.02^{\dagger}$ & 0.01 & -0.01 & 0.01 \\
\hline pre_corp_partnership & $-0.10^{*}$ & 0.05 & $0.06^{\dagger}$ & 0.03 & 0.04 & 0.03 \\
\hline services & \multicolumn{2}{|c|}{$0.11 * * * 0.02$} & $-0.07 * * *$ & 0.02 & $-0.04 * * *$ & 0.00 \\
\hline married & 0.02 & 0.05 & -0.01 & 0.03 & -0.01 & 0.02 \\
\hline female & \multicolumn{2}{|c|}{$0.06 * * * 0.00$} & $-0.04 * * *$ & 0.00 & $-0.02 * * *$ & 0.00 \\
\hline owner_experience & \multicolumn{2}{|c|}{$0.00 * * * 0.00$} & $0.00 * * *$ & 0.00 & $0.00 * * *$ & 0.00 \\
\hline business_age & \multicolumn{2}{|c|}{$0.00 * * * 0.00$} & $0.00 * * *$ & 0.00 & $0.00 * * *$ & 0.00 \\
\hline number_of_employees & $0.00^{\dagger}$ & 0.00 & $0.00^{\dagger}$ & 0.00 & $0.00^{\dagger}$ & 0.00 \\
\hline home_based_biz & 0.01 & 0.03 & -0.01 & 0.02 & 0.00 & 0.01 \\
\hline
\end{tabular}

${ }^{\dagger} p<0.10, * p<0.05, * * p<0.01, * * * p<0.001$ 
Businesses in period one (immediately after Hurricane Katrina) were either open or closed, measuring short-term recovery. In period two (2013), less success, same success and more success (comparing pre-Katrina and post-Katrina success) were used to describe the states of long-term resilience (i.e., survived, recovered, and resilient).

The aim of this study was to measure the impact that cash flow problems and financial intermingling had on recovery and resilience in small businesses following a natural disaster. This study finds that recovery and resilience are impacted differently by cash flow problems and financial intermingling. Recovery was a short-term state measured by a business operating (versus being closed). Marshall and Schrank (2014) explained that a business is "recovered when it re-stabilizes as defined by some standard measurable criteria" (p. 609). Furthermore, resilience embodied a longer-term, stable and thriving state (measured by having more success after Katrina than before). Marshall and Schrank (2014) referred to resilience as "a system's capacity to absorb disturbance and re-organize into a fully functioning system" (p. 609).

Past studies investigated how cash flow problems influenced financial intermingling between business and household (Zuiker et al. 2002). We extended those studies by investigating how each individual process affected business recovery and resilience. The results indicate that cash flow problems and financial intermingling did not play a role in short-term survival, but did have an effect on long-term resilience. A businesses' response to a natural disaster had a large effect on business success and survival (Haynes et al. 2007; Olson et al. 2003).

Our study finds that owner and business characteristics along with hurricane damage had a larger influence on recovery than business cash flow problems and bootstrapping methods. In fact, major damage by Katrina decreased the probability of business survival by $10 \%$. For small business survival, storm damage incurred was the largest source of closure. Other owner and business characteristics affected survival probability by less than $3 \%$. In the short-run, female and married business owners were less likely to have businesses that survived the natural disaster. Married business owners may have more concern over household and family recovery than business recovery. Female business owners may have less adaptive capacity to deal with disasters in the short and long-run.

In regard to business type and business success, we find that being in the service industry or a home-based business made businesses more likely to experience post-Katrina success. For service industry businesses, their customer base may be more stable, as they offered a service the customer was not willing or able to do themselves. Given this relationship, pre- and post-Katrina, these customers still needed the service that business offered. When considering home-based businesses, it was likely that those with home-based businesses are able to recover more quickly, as they only have one building structure to repair, rather than a home and a separately located business. These home-based business owners were able to repair their homes more immediately and had reduced operational or recovery costs due to their single structure operation.

More experienced small business owners were more likely to be resilient following Hurricane Katrina. It can be assumed that more experienced owners were more stable pre-Katrina, which may have given them more resources to aid in their recovery. Business owners who had cash flow problems before they experienced Hurricane Katrina were more likely to have cash flow problems after Katrina. Also, if strong storm damage was incurred, even businesses without pre-Katrina cash flow problems may begin to experience issues when trying to recover. Hiramatsu and Marshall (2018) found that even eight years following Katrina, many businesses were struggling to recover. Furthermore, simply getting a loan or other financial assistance after the disaster did not necessarily help small businesses, it simply added to their debt load. Hiramatsu and Marshall (2018) also found a negative relationship between post-Katrina cash flow problems and post-Katrina success.

The overlap of family and business resources are heavily integrated in small businesses. Changes in the family system affect the business system and vice versa (Lee et al. 2015; Niehm et al. 2009). The Sustainable Family Business Model (SFBM) has been the theoretical framework for many small and family business studies since its creation (Stafford et al. 1999). However, for natural disaster research, the family is often left out of the analysis (Haynes et al. 2018). Our research makes a contribution to the literature by examining the influences of family and business on small business recovery and resilience after a natural disaster. Businesses who had cash flow problems before Katrina may have been able to survive the storm and restart operation, but their long-term success would likely be affected in a negative way. Similarly, small businesses that intermingled business and household finances may have been able to restart business operation (possibly at the household's expense), but longterm resilience was most likely diminished.

The sample in this study consists of both family and non-family businesses and may be a limitation since family businesses may have different financial intermingling/bootstrapping behavior than non-family businesses. Another limitation is that the results are specific to small- and mediumsized businesses in Mississippi. Due to the catastrophic nature of hurricanes, other disasters (natural or man-made) may have differing impacts on small business cash flow problems and financial intermingling.

Consistent with previous research, this study found that gender differences do exist within small businesses. Being a 
female business owner had a negative influence on resilience, therefore educational programs could be offered to both female and male business owners who reside in areas where natural disasters are more likely to occur. Seminars, workshops, and training programs on topics such as estimating costs and expenses as well as preparing and managing business finances would help owners be prepared to weather the disaster (and would help to mitigate potential cash flow problems).

Business consultants and other professionals working with small firms might need to provide clients with bootstrapping techniques; small businesses could be at greater risk without a clear understanding of these methods. Using this information, business consultants and professionals can be prepared to assist small businesses suffering during the COVID-19 pandemic. These businesses may be seeking financial assistance or participating in financial intermingling in order to survive during the economic shut down. We may see that firms that were shut down for a substantial amount of time solved their business cash flow problems with family funds, thereby putting the household and the business at risk. In accordance, our results indicate that both financial intermingling and seeking financial assistance decrease the chances of business resilience in the long run. Danes et al. (2009) findings suggest that during difficult times and when financial capital is absent, human and social capital become important for small business survival and recovery. Small business loans or professional advice could help these small businesses from making unwise financial decisions during and following COVID-19 or a similar business disruption.

Funding This article is based upon material from the Purdue University Project "Small Business Survival and Demise after a Natural Disaster", supported by NSF Grant \#0856221-CMMI and "Small Business Disaster Recovery Process: An Analysis of Rural Communities in Mississippi" supported by USDA-NIFA Grant \# 2011-67023-30609.

Code Availability Data analysis was conducted in STATA and code is available upon request.

\section{Compliance with Ethical Standards}

Conflict of interest The authors declare that they have no conflict of interest.

Ethical Approval The questionnaire and methodology for this study was approved by the Human Research Ethics committee of the Purdue University under IRB Protocol number: 0802006466.

\section{References}

Adekola, J., \& Clelland, D. (2019). Two sides of the same coin: Business resilience and community resilience. Journal of Contingencies and Crisis Management, 28(1), 50-60. https://doi. org/10.1111/1468-5973.12275.
Carter, R., \& Van Auken, H. (2006). Small firm bankruptcy. Journal of Small Business Management, 44(4), 493-512. https://doi. org/10.1111/j.1540-627x.2006.00187.x.

Corey, C. M., \& Deitch, E. A. (2011). Factors affecting business recovery immediately after Hurricane Katrina. Journal of Contingencies and Crisis Management, 19(3), 169-181. https://doi.org/10. 1111/j.1468-5973.2011.00642.x.

Danes, S. M., Stafford, K., Haynes, G., \& Amarapurkar, S. S. (2009). Family capital of family firms. Family Business Review, 22(3), 199-215. https://doi.org/10.1177/0894486509333424.

Greene, W. H. (2002). Econometric analysis (5th ed.). Upper Saddle River: Prentice Hall.

Haynes, G., \& Avery, R. (1996). Family businesses: Can the family and the business finances be separated? Preliminary results. Journal of Entrepreneurial and Small Business Finance, 5(1), 61-74.

Haynes, G. W., Danes, S. M., Schrank, H. L., \& Lee, Y. (2018). Survival and success of family-owned small businesses after hurricane Katrina: Impact of disaster assistance and adaptive capacity. Journal of Contingencies and Crisis Management, 27(2), 130-144. https://doi.org/10.1111/1468-5973.12245.

Haynes, G. W., Danes, S. M., \& Stafford, K. (2011). Influence of federal disaster assistance on family business survival and success. Journal of Contingencies and Crisis Management. https://doi.org /10.1111/j.1468-5973.2011.00637.x.

Haynes, G. W., Walker, R., Rowe, B. R., \& Hong, G. (1999). The intermingling of business and family finances in family-owned businesses. Family Business Review, 12(3), 225-239. https://doi. org/10.1111/j.1741-6248.1999.00225.x.

Haynes, G., Rowe, B., Walker, R., \& Hong, G. (2000). The differences in financial structure between women- and men-owned family businesses. Journal of Family and Economic Issues, 21(3), 209-226.

Haynes, G. W., Onochie, J. I., \& Muske, G. (2007). Is what's good for the business, good for the family: A financial assessment? Journal of Family and Economic Issues, 28(3), 395-409. https://doi. org/10.1007/s10834-007-9069-4.

Haynes, G. W., Onochie, J. I., Lee, M., Puryear, A. N., Rogoff, E. G., \& Heck, R. K. (2009). Financial intermingling in KoreanAmerican and Mexican-American small businesses. Journal of Developmental Entrepreneurship, 14(3), 297-310. https://doi. org/10.1142/s1084946709001284.

Hiramatsu, T., \& Marshall, M. I. (2018). The long-term impact of disaster loans: The case of small businesses after Hurricane Katrina. Sustainability, 10(7), 2364-2368. https://doi.org/10.3390/su100 72364.

Kneiding, C., \& Kritikos, A. S. (2013). Funding self-employment - The role of consumer credit. Applied Economics, 45(13), 1741-1749. https://doi.org/10.1080/00036846.2011.637895.

Lee, J., \& Stafford, K. (2013). Determinants on resource management decision of ethnic family businesses: Resource intermingling of financial resources and human resources. Consumer Interests Annual, 59, 155-166.

Lee, Y. G., Fitzgerald, M. A., Bartkus, K. R., \& Lee, M. (2015). Ethnic differences in the use of adjustment strategies and associations with perceived success in minority-owned family firms. New England Journal of Entrepreneurship, 18(1), 9-26. https://doi. org/10.1108/neje-18-01-2015-b001.

López-Gracia, J., \& Sánchez-Andújar, S. (2007). Financial structure of the family business: evidence from a group of small Spanish firms. Family Business Review, 20(4), 269-287. https://doi.org/1 0.1111/j.1741-6248.2007.00094.x.

Marshall, M. I., \& Schrank, H. L. (2014). Small business disaster recovery: A research framework. Natural Hazards, 72(2), 597616. https://doi.org/10.1007/s11069-013-1025-z.

Marshall, M. I., Niehm, L. S., Sydnor, S. B., \& Schrank, H. L. (2015). Predicting small business demise after a natural disaster: An 
analysis of pre-existing conditions. Natural Hazards, 79(1), 331354. https://doi.org/10.1007/s11069-015-1845-0.

McDonald, T. M., \& Marshall, M. I. (2017). Family business responses to household and business cash-flow problems. Journal of Family and Economic Issues, 39(1), 163-176. https://doi.org/10.1007/ s10834-017-9543-6.

Muske, G., Fitzgerald, M., Haynes, G., Black, M., Chin, L., MacClure, R., et al. (2009). The intermingling of family and business financial resources: Understanding the copreneurial couple. Journal of Financial Counseling and Planning, 20(2), 27-47.

Neeley, L., \& Van Auken, H. (2009). The relationship between owner characteristics and use of bootstrap financing methods. Journal of Small Business \& Entrepreneurship, 22(4), 399-412. https:// doi.org/10.1080/08276331.2009.10593462.

Niehm, L. S., Miller, N. J., Shelley, M. C., \& Fitzgerald, M. A. (2009). Small family business survival: Strategies for coping with overlapping family and business demands. Journal of Developmental Entrepreneurship, 14(3), 209-232. https://doi.org/10.1142/s1084 946709001314.

Olson, P., Zuiker, V. S., Danes, S., Stafford, K., Heck, R., \& Duncan, K. (2003). The impact of the family and the business on family business sustainability. Journal of Business Venturing, 18(5), 639-666. https://doi.org/10.1016/s0883-9026(03)00014-4.

Paul, J. J., Winter, M., Miller, N. J., \& Fitzgerald, M. A. (2003). Cross-institutional norms for timing and sequencing and the use of adjustment strategies in families affiliated with family-owned businesses. Marriage and Family Review, 35(1-2), 167-191. https ://doi.org/10.1300/j002v35n01_10.

Runyan, R. C. (2006). Small business in the face of crisis: Identifying barriers to recovery from a natural disaster. Journal of Contingencies and Crisis Management, 14(1), 12-26. https://doi.org/10.111 1/j.1468-5973.2006.00477.x.

Stafford, K., Duncan, K. A., Danes, S., \& Winter, M. (1999). A research model of sustainable family businesses. Family Business Review, 12(3), 197-208. https://doi.org/10.1111/j.1741-6248.1999.00197 .X.

Sydnor, S., Niehm, L., Lee, Y., Marshall, M., \& Schrank, H. (2016). Analysis of post-disaster damage and disruptive impacts on the operating status of small businesses after Hurricane Katrina. Natural Hazards, 85(3), 1637-1663. https://doi.org/10.1007/s1106 9-016-2652-y.

Torres, A. P., Marshall, M. I., \& Sydnor, S. (2018). Does social capital pay off? The case of small business resilience after Hurricane Katrina. Journal of Contingencies and Crisis Management, 27(2), 168-181. https://doi.org/10.1111/1468-5973.12248.

Van Auken, H. (2004). The use of bootstrap financing among small technology-based firms. Journal of Developmental Entrepreneurship, 9(2), 145-159.

Winborg, J., \& Landström, H. (2001). Financial bootstrapping in small businesses. Journal of Business Venturing, 16(3), 235-254. https ://doi.org/10.1016/s0883-9026(99)00055-5.

Winter, M., Danes, S. M., Koh, S. K., Fredericks, K., \& Paul, J. J. (2004). Tracing family businesses and their owners over time: Panel attrition, manager departure and business demise. Journal of Business Venturing, 19(4), 535-559. https://doi.org/10.1016/ s0883-9026(03)00061-2.

Wooldridge, J. M. (2013). Introductory econometrics: A modern approach (5th ed.). Mason, OH: South-Western.

Yilmazer, T., \& Schrank, H. (2006). Financial intermingling in small family businesses. Journal of Business Venturing, 21(5), 726-751. https://doi.org/10.1016/j.jbusvent.2005.04.011.

Yilmazer, T., \& Schrank, H. (2010). The use of owner resources in small and family owned businesses: Literature review and future research directions. Journal of Family and Economic Issues, 31(4), 399-413. https://doi.org/10.1007/s10834-010-9224-1.

Zuiker, V. S., Lee, Y., Olson, P., Danes, S., Van Guilder Dik, A., \& Katras, M. (2002). Business, family, and resource intermingling characteristics as predictors of cash flow problems in familyowned businesses. Journal of Financial Counseling and Planning, 13(2), 65-81.

Publisher's Note Springer Nature remains neutral with regard to jurisdictional claims in published maps and institutional affiliations. 